\title{
PENGUKURAN KINERJA PERUSAHAN MENGGUNAKAN METODE OBJECTIVE MATRIKS (OMAX) DAN ANALYTICAL HIERARCHY PROCESS (AHP)
}

\author{
Syarif Hidayatullah ${ }^{1}$, Said Salim Dahda ${ }^{2}$, Elly ismiyah ${ }^{3}$ \\ Program Studi Teknik Industri, Fakultas Teknik, Universitas Muhammadiyah Gresik \\ Jl. Sumatera 101 GKB, Gresik 61121, Indonesia \\ e-mail : arifarekdondong@gmail.com
}

\begin{abstract}
ABSTRAK
Kinerja merupakan salah satu faktor penting untuk penunjang kelangsungan hidup suatu perusahaan dengan cara menganalisa dan mengevaluasi keluaran yang didapat berdasarkan atas tingkat unjuk kerjanya selama periode tertentu. untuk mengetahui tingkat kinerja perusahaan saat ini, maka perlu dilakukan pengukuran kinerja. Salah satu Metode untuk mengukur kinerja perusahaan adalah metode Objective Matriks atau OMAX dan penelitian ini mengacu pada langkah-langkah, yaitu menentukan kriteria dengan Seven Steps Methodolgy, penentuan bobot dengan Analytical Hierarchy Process, penentuan level-level pada objective matriks, perhitungan index produktivitas, dan Evaluasi dengan traffic light system untuk pengelompokan level pencapaian indikator dan melakukan perbaikan untuk level indikator yang buruk.Dari hasil pengukuran kinerja selama periode Januari sampai September 2021 terjadi empat kali penurunan produktivitas pada bulan Februari sebesar -70\%, Mei sebesar $-3 \%$, Juni $-11 \%$ dan Agustus sebesar -59\%. Berdasarkan evaluasi dengan traffic light system rasio rumah yang terjual mempunyai pengaruh besar terhadap penurunan produktivitas, untuk meningkatkan penjualan rumah perlu dilakukan pengendalian pada marketing ketika melakukan promosi dan juga mengevaluasi sistem promosi yang di gunakan perusahan.
\end{abstract}

Kata kunci :Pengukuran Kinerja, Objective Matrik, Analytical Hierarchy Proces

\section{ABSTRACT (B.Inggris, 150-200 kata) 10 pt}

Performance is one of the important factors to support the survival of a company by analyzing and evaluating the output obtained based on the level of performance during a certain period. To determine the current level of company performance, it is necessary to measure performance. One of the methods to measure company performance is the Objective Matrix or OMAX method and this research refers to the steps, namely determining the criteria with the Seven Steps Methodology, determining the weights using the Analytical Hierarchy Process, determining the levels in the objective matrix, calculating the productivity index, and Evaluation with a traffic light system for grouping indicator achievement levels and making improvements to poor indicator levels. From the results of performance measurement during the period January to September 2021, there were four times the decline in productivity in February of $-70 \%$, May of $-3 \%$, June $-11 \%$ and August at $-59 \%$. Based on the evaluation with the traffic light system, the ratio of houses sold has a major influence on the decline in productivity, to increase home sales, it is necessary to control marketing when doing promotions and also evaluate the promotional system used by the company.

Keywords : Performance Measurement, Objective Matrik, Analytical Hierarchy Proces

\section{Jejak Artikel}

Upload artikel : 15 Desember 2021

Revisi : 25 Desember 2021

Publish : 31 Januari 2022

\section{PENDAhuluan}

Di era globalisasi mengakibatkan persaingan bisnis semakin ketat, maka perusahaan dihadapkan pada pencapaian jangka panjang (Salomon et al., 2017). Menurut salomon juga berkembangnya teknologi juga menjadi alternatif untuk memperluas jaringan perusahaan untuk dapat bersaing selain harus menghasilakan produk dan jasa yang sesuai dengan harapan pelanggan, tentunya hal tersebut tidak dapat dicapai jika kinerja perusahaanya buruk.

Pengukuran kinerja dalam sebuah perusahaan merupakan hal yang sangat penting untuk mengevaluasi terhadap performa perusahaan dan perencanaan visi, misi dan tujuan di masa mendatang. Karena, Kinerja adalah hasil seseorang secara keseluruhan selama periode tertentu di dalam melaksanakan tugas, seperti 
standar hasil kerja, target atau sasaran atau kriteria yang telah ditentukan terlebih dahulu dan telah disepakati bersama (Salomon et al., 2017). Pimpinan perusahaan cenderung kesulitan untuk melihat dan mengukur kinerja dari perusahaannya, hal ini disebabkan oleh tidak adanya ukuran baku yang dapat dijadikan patokan dalam mengukur kinerja (Kaluku \& Pakaya, 2017).

CV Astahanawa Propertindo adalah perusahaan yang bergerak dalam bidang jasa Pemasaran rumah, untuk memenuhi kebutuhan tempat tinggal para pelangan. CV Asthanawa Propertindo terletak di RUKO PPS, Jalan Berlian Biru No 44/59, Gresik, Jawa Timur. Selama ini, CV Asthanawa Propertindo hanya berfokus pada pengukuran kinerja didasarkan pada aspek finansial saja, Sedangkan untuk aspek-aspek non finansial kurang diperhatikan salah satunya kualitas pelayanan dan sumberdaya. Oleh karena itu dibutuhkan metode pengukuran kinerja yang dapat mengukur kinerja perusahaan dengan mempertimbangkan aspek lain selain finansial

Adapun data penjualan perumahan CV Asthanawa Propertindo seperti Gambar 1 yang menjadi patokan kinerja perusahaan.

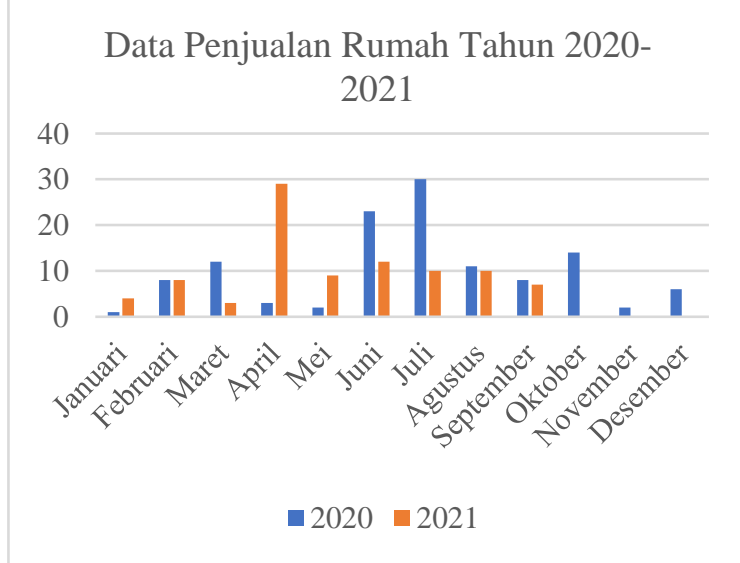

Gambar 1. Data Penjualan Rumah tahun 20202021

\section{Sumber: Dokumen Perusahaan}

Dari data penjualan di Gambar 1.1 rumah yang berhasil di jual oleh perusahaan dari bulan Januari 2020 sampai September 2021 total 213 Rumah. Dari bulan Januari 2020 sampai September 2021 mengalami fluktuasi dan total rumah yang terjual adalah 213 Rumah. Berdasarkan wawancara dengan pimpinan perusahaan CV Asthanawa Propertindo, kriteria pengukuran kinerja pada perusahaan hanya mengacu pada faktor finansial saja yaitu fee hasil penjualan rumah. Menurut pimpinan perusahaan, hal tersebut masih belum dapat menggambarkan kinerja perusahaan secara keseluruhan. Hal ini sejalan dengan(Sari \& Yuniarti, 2018) yang menyatakan faktor dalam pengukuran kinerja yang hanya memperhatikan faktor finansial tidak dapat memenuhi harapan Stakeholder (Organisasi dan Pelanggan Organisasi). Oleh karena itu, diperlukan pengukuran kinerja dengan kriteria yang mengakomodasi harapan Stakeholder. Salah satu langkah untuk memasukkan harapan Stakeholder terlihat dari misi suatu organisasi dengan mengidentifikasi kriteria-kriteria yang tepat untuk dipakai dalam pengukuran kinerja. Seven Steps Methodolgy merupakan salah satu metodologi yang banyak digunakan untuk pengembangan kriteria-kriteria yang dapat memenuhi harapan banyak pihak, hal ini terlihat pada prosedur Seven Steps Methodolgy yang memulai dengan mengdentifikasikan misi, harapan organisasi, dan indeks yang akan dijadikan kriteria pengukuran kinerja (Damayanti \& Widianti, 2015). Tujuan utama dan harapan pelanggan yang ditetapkan melalui misi sebuah organisasi (Damayanti \& Widianti, 2015).

Pengukuran kinerja yang mempunayi banyak kriteria merupakan salah satu bentuk pengukuran kinerja parsial (Damayanti \& Widianti, 2015). Pengukuran yang dapat banyak di pakai adalah Objective Matriks (OMAX), Model pengukuran ini mempunyai ciri unik, yaitu kriteria performansi kelompok kerja digabungkan pada suatu matriks, Setiap kriteria performansi memiliki sasaran berupa jalur khusus perbaikan serta memiliki bobot sesuai dengan tingkat kepentingan terhadap tujuan kinerja (Damayanti \& Widianti, 2015). Metode Objective Matriks (OMAX) merupakan metode yang dapat mengkombinasikan pendekatan kuantitatif dan kualitatif, yang Dapat digunakan untuk mengukur aspek kinerja dengan mempertimbangkan suatu unit kerja (Salomon et al., 2017). Selanjutnya mengevaluasi (scoring system), salah satu metode yang banyak dipakai adalah Traffic Light System (TLS) untuk mengetahui skor dari tiap kriteria. TLS termasuk dalam penilaian OMAX, yang berhubungan dengan scoring system yang digunakan sebagai tanda score yang diperoleh dari suatu Kriteria kinerja apakah memerlukan suatu perbaikan atau tidak, Metode pengukuran kinerja OMAX TLS digunakan karena lebih mudah dipahami, terlihat dengan sangat jelas kinerja apa yang belum tercapai dan butuh perbaikan dengan segera (Sari \& Yuniarti, 2018). 
Pada proses perhitungan tingkat kinerja pada OMAX diperlukan bobot untuk masing-masing kritetria. Metode Analytical Hierarchy Process (AHP) di gunakan untuk membobotkan kriteriakriteria yang dibutukan dalam mengukur kinerja perusaahan. Pada dasarnya AHP merupakan metode yang dapat memecahkan suatu masalah yang kompleks dan tidak terstruktur ke dalam komponen-komponennya, untuk mengatur komponen-komponen tersebut dalam suatu hierarki, kemudian memasukkan nilai numerik sebagai pengganti persepsi manusia dalam melakukan perbandingan relatif, dan akhirnya mendapatkan suatu sintesa yang menetapkan urutan dan nilai prioritas pada komponenkomponen tersebut (Ilhami \& Rimantho, 2017).

Penelitian ini diharapkan dapat menjadi bahan pertimbangan dan sebagai masukan untuk perusahaan agar bisa mengetahui krietria yang sesuai dengan aktifitas perusahaan dan nilai kinerja perusahaan. setelah mengetahui hal tersebut, perusahaan juga bisa meningkatkan atau memperbaiki kinerja yang belum tercapai

\section{METODOLOGI PENELITIAN}

Ada beberapa metode yang dapat digunakan untuk mengukur kinerja perusahaan. Salah satu metode yang digunakan dalam penelitian ini adalah metode Objective Matriks (OMAX). Metode Objective Matriks (OMAX) merupakan metode yang dapat mengkombinasikan pendekatan kuantitatif dan kualitatif, yang Dapat digunakan untuk mengukur aspek kinerja dengan mempertimbangkan suatu unit kerja (Salomon et al., 2017).

Kriteria yang digunakan penelitihan ini untuk mengukur kinerja perusahaan di bentuk berdasarkan Seven Steos Methodolgy adapun langkah langkahnya sebagai berikut

Tabel 1 Langkah-Langkah Seven Steps Methodolgy

\begin{tabular}{|c|c|l|}
\hline No & Langkah & \multicolumn{1}{c|}{ Rincian } \\
\hline 1 & $\begin{array}{c}\text { Mission } \\
\text { Statement }\end{array}$ & $\begin{array}{l}\text { Memahami misi utama } \\
\text { dari perusahaan }\end{array}$ \\
\hline 2 & Expectation & $\begin{array}{l}\text { Mengidentifikasi } \\
\text { harapan terhadap hasil } \\
\text { pekerjaan perusahaan }\end{array}$ \\
\hline 3 & Key Outputs & $\begin{array}{l}\text { Mengetahui output } \\
\text { kunci dari perusahaan }\end{array}$ \\
\hline
\end{tabular}

\begin{tabular}{|c|c|l|}
\hline 4 & $\begin{array}{c}\text { Major } \\
\text { Functions }\end{array}$ & $\begin{array}{l}\text { Mengetahui kegiatan } \\
\text { dari perusahan dan } \\
\text { input yang dibutuhkan } \\
\text { dalam menghasilkan } \\
\text { output kunci }\end{array}$ \\
\hline 5 & $\begin{array}{c}\text { Output } \\
\text { Measurement } \\
\text { Selection }\end{array}$ & $\begin{array}{l}\text { Memilih output kunci } \\
\text { yang akan digunakan } \\
\text { dalam pengukuran } \\
\text { kinerja dari perusahaan }\end{array}$ \\
\hline 6 & $\begin{array}{c}\text { Measurement } \\
\text { Selection }\end{array}$ & $\begin{array}{l}\text { Memilih input kunci } \\
\text { yang akan digunakan } \\
\text { dalam pengukuran } \\
\text { kinerja dari } \\
\text { perusaahaan }\end{array}$ \\
\hline 7 & $\begin{array}{l}\text { pembangunan indeks, } \\
\text { menghubungkan antara } \\
\text { output kunci dan input } \\
\text { kunci pengukuran } \\
\text { untuk mengetahui } \\
\text { kriteria yang akan di } \\
\text { ukur }\end{array}$ \\
\hline & $\begin{array}{c}\text { contruction } \\
\text { Index }\end{array}$ \\
\hline
\end{tabular}

(Rahman \& Ismail, 2015)

Pada penelitihan ini pembobotan tiap kriteria dengan menggunakan metode AHP yang didapat melalui kuisioner berbentuk perbandingan berpasangan yang selanjutnya diolah dengan menggunakan software exper choise 11. Selanjutnya Pengukuran kinerja perusahaan dilakukan dengan menggunakan metode OMAX yang bertujuan untuk mengetahui nilai pencapaian dari masingmasing kriteria dengan menggunakan nilai range antara 0-10 dari 3 level yaitu, level 10 merupakan target yang igin di capai perusahaan, level 3 merupakan nilai standar, dan level 0 merupakan capaian terburuk yang pernah dialami perusahaan (Neely \& Adams, 2004). Pada pengukuran ini di padukan dengan penilaian Traffic Light System (TLS) yang diklasifikasi dalam tiga indikator, warna hijau (skor 8-10), kuning (skor 4-7) dan merah (skor 0-3) (Kustiadi \& Hasbullah, 2019).

Tabel 2. Perhitungan Performansi Dengan Penilaian TLS

\begin{tabular}{|c|c|l|l|l|}
\hline \multicolumn{2}{|c|}{ Kode } & Kriteria 1 & Kriteria 2 & Dst \\
\hline \multicolumn{2}{|c|}{ Rasio } & & & \\
\hline Target & 10 & & & \\
\hline & 9 & & & \\
\cline { 2 - 5 } & 8 & & & \\
\hline
\end{tabular}




\begin{tabular}{|c|c|l|l|l|}
\hline & 7 & & & \\
\hline & 6 & & & \\
\hline & 4 & & & \\
\hline Standar & 3 & & & \\
\hline & 2 & & & \\
\hline & 1 & & & \\
\hline $\begin{array}{c}\text { Pencapaian } \\
\text { Terburuk }\end{array}$ & 0 & & & \\
\hline Score & & & & \\
\hline Bobot & & & \\
\hline Nilai & & & \\
\hline Total & & & \\
\hline
\end{tabular}

(Sirait, 2020)

Rancangan sistem pengukuran kinerja OMAX yang dipadukan dengan penilaian TLS untuk mengetahui mana saja kriteria yang perlu perbaiakan dan tidak perlu perbaiakan.

\section{HASIL DAN PEMBAHASAN}

\subsection{Penentuan Kriteria}

Pada tahap ini menentukan kriteria dengan mengunakan Seven Steps Metodology berdasarkan misi perusahaan, yang terbagi menjadi 7 tahap, yaitu:

1. Misi perusahaan

- Mewujudkan kualitas terbaik pada pelayanan jasa pembelian properti.

- Mencapai pertumbuhan jumlah penjualan diatas rata-rata pertumbuhan industri agen properti regional dan nasional.

- Membangun sumber daya yang disiplin, dan berintegritas tinggi di bidang angen properti

2. Harapan perusahaan

- Menghasilkan kualitas pelayanan terbaik jasa pembelian propeti dalam melayani costumer perusahaan

- Menghasilkan penjualan yang lebih baik dari bulan sebelumya agar dapat mencapai pertumbuhan pendapatan di atas rata rata industri agen properti.

- Menghasilkan sumber daya manusia yang mempunyai ras disiplin yang tinggi, jujur dan bertanggung jawab atas pekerjaannya.

3. Key Output (Output kunci) a. Jumlah customer complain

b. Jumlah customer ( customer yang melakukan boking fee/ posisi rumah )

c. Jumlah jam kerja produktif

d. Biaya Pemasaran

e. Jumlah rumah yang terjual

f. Jumlah karyawan yang datang tepat waktu.

g. Jumlah total hari absen karyawan

4. Major function

a. Jumlah Marketing

b. Jumlah jam kerja

c. Jumlah Rumah yang dijual ( unit yang tersedia )

d. Anggaran Pemasaran

e. Jumlah karyawan yang terlambat

f. Jumlah total kehadiran kehadiran karyawan

5. Output mesurement selection
a. Jumlah complain
b. Jumlah customer
c. Jumlah rumah yang terjual
d. Biaya Pemasaran
e. Jumlah Total hari absen Karyawan

6. Input mesurement selection

a. Jumlah Marketing

b. Jumlah unit yang tersedia

c. Anggaran pemasaran

d. Jumlah total hari kehadiran karyawan

7. Indeks Contruction

pembangunan indeks (rasio), dengan menghubungkan output kunci dan input kunci pengukuran.

1. Kriteria $1=$ Rasio Complain

$$
=\frac{\text { Jumlah Costumer Complain }}{\text { Jumlah Customer }}
$$

2. Kriteria $2=$ Rasio Costumer

$$
=\frac{\text { Jumlah Customer }}{\text { Jumlah Marketing }}
$$

3. Kriteria $3=$ Rasio Rumah Yang terjual $=\frac{\text { Jumlah Rumah Yang Terjual }}{\text { Unit Yang Tersedia }}$

4. Kriteria $4=$ Rasio Biaya Pemasaran $=\frac{\text { Biaya Pemasaran }}{\text { Anggaran Pemasaran }}$

5. Kriteria $5=$ Rasio Absensi Karyawan $=\frac{\text { Jumlah Total Hari Absen Karyawan }}{\text { Jumlah Total Hari Kehadiran Karyawan }}$ 


\subsection{Data Target}

Target merupakan sasaran yang ingin dicapai perusahaan pada tahun berikutnya. Target merupakan besaran yang ingin dicapai perusahaan yang naik turunya disesuaikan dengan kriteria produktivitasnya. Tabel 3

Tabel 3 Data Target

\begin{tabular}{|l|c|}
\hline \multicolumn{1}{|c|}{ Kriteria } & \multicolumn{1}{c|}{$\begin{array}{c}\text { Target } \\
\text { produktivitas }\end{array}$} \\
\hline Rasio Complain & Turun 25\% \\
\hline Rasio Customer & Naik 50\% \\
\hline $\begin{array}{l}\text { Rasio Rumah yang } \\
\text { Terjual }\end{array}$ & Naik 50\% \\
\hline Rasio Biaya Pemasaran & Turun 10\% \\
\hline $\begin{array}{l}\text { Rasio Absensi } \\
\text { Karyawan }\end{array}$ & Turun 50\% \\
\hline
\end{tabular}

(Sumber: Pengolahan Data, 2021)

\subsection{Pembobotan Dengan AHP}

Penentuan bobot kepentingan di dalam penilaian perbandingan antar kriteria yang di anggap penting yang berasal dari kusioner perbandingan berpasangan. Dalam matriks tersebut akan mengambarkan kontribusi pengaruh tiap kriteria dalam mengukur kinerja perusahaan, dimana nilai dari kusioner perbandingan berpasangan dari tiap kriteria yang di peroleh dari 4 responden yaitu, Direktur, Manajer Pemasaran, HRD, dan Head Of Marketing kemudian dihitung dengan Software Expert Chooise 11. Tabel 4 merupakan bobot tiap kriteria.

Tabel 4 Bobot Tiap Kriteria

\begin{tabular}{|l|c|}
\hline \multicolumn{1}{|c|}{ Kriteria } & Bobot \\
\hline Rasio Complain & 0,43 \\
\hline Rasio Customer & 0,26 \\
\hline Rasio Rumah Yang Terjual & 0,06 \\
\hline Rasio Biaya Pemasaran & 0,16 \\
\hline Rasio Absensi katyawan & 0.09 \\
\hline \multicolumn{1}{|c|}{ Total } & 1 \\
\hline
\end{tabular}

(Sumber: Pengolahan Data, 2021)

Jumlah total bobot semua kriteria $=1$ sesuai kaidah dimana jumlah total harus bernilai 1 dan Consistensi Rasio < 0,1

\subsection{Pengukuran Dengan OMAX 3.4.1 Perhitungan Rasio}

Tabel 5 merupakan nilai dari tiap rasio selama periode pengukuran mulai dari bulan Januari sampai bulan September 2021

Tabel 5 Nilai Rasio

\begin{tabular}{|c|c|c|c|c|c|}
\hline \multicolumn{7}{|c|}{ Nilai Tiap Kriteria (rasio) } \\
\hline Bulan & R 1 & R 2 & R 3 & R 4 & R 5 \\
\hline Januari & 0 & 0.22 & 0.004 & 0.936 & 0.097 \\
\hline Februari & 1 & 0.44 & 0.009 & 0.899 & 0.076 \\
\hline Maret & 0.2 & 2.77 & 0.003 & 0.973 & 0.088 \\
\hline April & 0 & 5.11 & 0.036 & 1.516 & 0.070 \\
\hline Mei & 0.03 & 3.11 & 0.011 & 1.371 & 0.080 \\
\hline Juni & 0 & 0.22 & 0.015 & 0.973 & 0.033 \\
\hline Juli & 0 & 2.44 & 0.007 & 0.973 & 0.049 \\
\hline Agustus & 0.21 & 1.55 & 0.007 & 0.961 & 0.097 \\
\hline September & 0.03 & 3.22 & 0.005 & 0.989 & 0.044 \\
\hline Max & $\mathbf{0}$ & $\mathbf{5 , 1 1}$ & $\mathbf{0 , 0 3 6}$ & $\mathbf{0 , 8 9 9}$ & $\mathbf{0 , 0 3 3}$ \\
\hline Average & $\mathbf{0 . 1 6}$ & $\mathbf{2 . 1 2}$ & $\mathbf{0 , 0 1 1}$ & $\mathbf{1 . 0 0 2}$ & $\mathbf{0 , 0 7 0}$ \\
\hline Min & $\mathbf{1}$ & $\mathbf{0 . 2 2}$ & $\mathbf{0 , 0 0 3}$ & $\mathbf{1 . 5 1 6}$ & $\mathbf{0 , 0 9 7}$ \\
\hline
\end{tabular}

\subsubsection{Penentuan Nilai Level OMAX}

Nilai level produktivitas didapatkan dari nilai rasio tiap kriteria yang terbagi menjadi tiga level yaiu level 10 merupakan target yang ingin dicapai perusahaan pada tahun berikutnya. level 3 merupakan nilai standar yang di tentukan dari rata-rata tiap rasio, level 0 merupakan nilai terendah dari perhitungan rasio produktivitas.

Tabel 6 Nilai Level OMAX

\begin{tabular}{|l|c|c|c|}
\hline Kriteria & $\begin{array}{c}\text { Level } \\
\mathbf{0}\end{array}$ & $\begin{array}{c}\text { Level } \\
\mathbf{3}\end{array}$ & $\begin{array}{c}\text { Level } \\
\mathbf{1 0}\end{array}$ \\
\hline Rasio Complain & 1 & 0.16 & 0 \\
\hline Rasio Customer & 0.22 & 2.12 & 7,665 \\
\hline $\begin{array}{l}\text { Rasio Rumah yang } \\
\text { Terjual }\end{array}$ & 0.003 & 0.011 & 0,054 \\
\hline $\begin{array}{l}\text { Rasio Biaya } \\
\text { Pemasaran }\end{array}$ & 1.516 & 1.002 & 0,809 \\
\hline $\begin{array}{l}\text { Rasio Absensi } \\
\text { Karyawan }\end{array}$ & 0.097 & 0.07 & 0,016 \\
\hline
\end{tabular}

(Sumber : Pengolahan Data, 2021)

\subsubsection{Penentuan nilai interval}

Nilai Interval merupakan nilai yang mungkin dicapai setiap kriteria sebelum sasaran akhir. Berikut perhitungan skala 1-2 dan 4-9 :

Contoh perhitungan skala untuk level 1- level 2 pada rasio complain

$$
\begin{aligned}
& (\text { skala } 1-2) \frac{\text { level } 3-\text { level } 0}{3-0} \\
& (\text { skala } 1-2) \frac{0,16-1}{3-0}=-0,28
\end{aligned}
$$


Contoh perhitungan skala untuk level 4 - level 9 pada rasio complain

$$
\begin{aligned}
& (\text { skala } 4-9) \frac{\text { level } 10-\text { level } 3}{10-3} \\
& (\text { skala } 1-2) \frac{0-0,16}{10-3}=-0.022
\end{aligned}
$$

Tabel 7 Nilai Interval

\begin{tabular}{|l|c|c|}
\hline \multicolumn{1}{|c|}{ Kriteria } & $\begin{array}{c}\text { Interval } \\
\mathbf{0 - 3}\end{array}$ & $\begin{array}{c}\text { Interval } \\
\mathbf{3 - 1 0}\end{array}$ \\
\hline Rasio Complain & -0.28 & -0.022 \\
\hline Rasio Customer & 0.633 & 0.792 \\
\hline $\begin{array}{l}\text { Rasio Rumah } \\
\text { yang Terjual }\end{array}$ & 0.002 & 0.006 \\
\hline $\begin{array}{l}\text { Rasio Biaya } \\
\text { Pemasaran }\end{array}$ & -0.171 & -0.027 \\
\hline $\begin{array}{l}\text { Rasio Absensi } \\
\text { Karyawan }\end{array}$ & -0.009 & -0.007 \\
\hline
\end{tabular}

(Sumber: Pengolahan Data, 2021)

\subsubsection{Indikator Performansi}

Selanjutnya adalah menghitung indikator performansi, dimana indikator performansi ini dihitung mulai dari bulan Januari 2021 sampai bulan September 2021, tabel perhitungan indikator performansi bisa dilihat di lampiran 1. Setelah semua sel sel terisi selanjutnya menentukan skor yang didapat dari nilai Rasio yang mendekati nilai dari level 10 sampai 0 dan dipadukan dengan penilaian Traffic Light System. Perhitungan indikator performansi pada bulan Januari 2021 bisa dilihat pada lampiran 1 .

Rekapitulasi Indikator performansi tiap periode dapat di lihat pada tabel tabel...... performansi paling tinggi berada pada bulan April sebesar 6,81 begitupun sebaliknya performansi paling rendah berada pada bulan Februari sebesar 1.51.

Tabel 8 Indikator Performansi

\begin{tabular}{|c|c|}
\hline Bulan & $\begin{array}{c}\text { Indikator } \\
\text { Performansi }\end{array}$ \\
\hline Januari & 5.1 \\
\hline Februari & 1.51 \\
\hline Maret & 5.64 \\
\hline April & 6.81 \\
\hline Mei & 6.57 \\
\hline Juni & 5.84 \\
\hline Juli & 6.23 \\
\hline
\end{tabular}

\begin{tabular}{|c|c|}
\hline Agustus & 2.51 \\
\hline September & 5.66 \\
\hline
\end{tabular}

(Sumber : Pengolahan Data, 2021)

\subsubsection{Indeks Produktivitas}

Indeks produktivitas dilakukan untuk mengetahui kenaikan atau penurunan selama periode Januari sampai September 2021, Perhitungan menggunakan rumus :

$$
\begin{aligned}
& (\text { ip })=\frac{(I P) \text { saat ini }-(\text { IP)sebelumnya }}{(\text { IP) sebelumnya }} \times 100 \% \\
& \left(\text { ip) }=\frac{1,51-5,1}{5,1} \times 100 \%=-70 \%\right.
\end{aligned}
$$

Tabel 9 Indeks Produktivitas

\begin{tabular}{|c|c|c|}
\hline Bulan & $\begin{array}{c}\text { Indikator } \\
\text { Performansi }\end{array}$ & $\begin{array}{c}\text { Indeks } \\
\text { Produktifitas }\end{array}$ \\
\hline Januari & 5.1 & $0 \%$ \\
\hline Februari & 1.51 & $-70 \%$ \\
\hline Maret & 5.64 & $273 \%$ \\
\hline April & 6.81 & $20 \%$ \\
\hline Mei & 6.57 & $-3 \%$ \\
\hline Juni & 5.84 & $-11 \%$ \\
\hline Juli & 6.23 & $6 \%$ \\
\hline Agustus & 2.51 & $-59 \%$ \\
\hline September & 5.66 & $125 \%$ \\
\hline
\end{tabular}

(Sumber: Pengolahan Data, 2021)

Penurunan produktifitas terbesar berada pada bulan Februari sebesar $-70 \%$, begitupun sebaliknya kenaikan produktivitas terbesar berada pada bulan april sebesar 273\%. Selanjutnya kita evaluasi terkait kriteria yang menyebabkan penurunan produktivitas.

\subsubsection{Evaluasi Traffic Light System}

Selanjutnya mengevaluasi Traffic Light System, untuk mengetahui capaian kinerja dan juga kriteria mana yang mempunyai pengaruh besar terhadap rendahnya produktivitas perusahaan CV Asthanawa Propertindo.

Rekapitulasi capaian kinerja tiap periode dengan penilaian traffic light system dari periode bulan Januari 2021 sampai Bulan September 2021 dapat di lihat pada tabel 10

Tabel 10 Evaluasi Traffic Light System

\begin{tabular}{|l|l|l|l|l|l|}
\hline \multicolumn{7}{|c|}{ Evaluasi TLS } \\
\hline Bulan & R 1 & R 2 & R 3 & R 4 & R 5 \\
\hline
\end{tabular}




\begin{tabular}{|c|c|c|c|c|c|}
\hline Januari & 0 & 0.22 & 0.004 & 0.936 & 0.097 \\
\hline Februari & 1 & 0.44 & 0.009 & 0.889 & 0.076 \\
\hline Maret & 0.2 & 2.77 & 0.033 & 0.973 & 0.088 \\
\hline April & 0 & 5.11 & 0.036 & 1.516 & 0.07 \\
\hline Mei & 0.03 & 3.11 & 0.011 & 1.371 & 0.08 \\
\hline Juni & 0 & 0.22 & 0.015 & 0.973 & 0.033 \\
\hline Juli & 0 & 2.44 & 0.007 & 0.973 & 0.049 \\
\hline Agustus & 0.21 & 1.55 & 0.007 & 0.961 & 0.097 \\
\hline September & 0.03 & 3.22 & 0.005 & 0.989 & 0.044 \\
\hline
\end{tabular}

(Sumber : Pengolahan Data, 2021)

pencapaian kinerja tiap kriteria pada periode bulan Januari sampai September 2021 dengan penilaian traffic light system. Warna hijau menunjukan bahawa kriteria produktivitas telah mencapai target Produktivitas yang diinginkan dengan rentang nilai 8-10, warna kuning menunjukan bahwa kriteria produktivitas mendekati target tapi belum mencapai target produktivitas dengan rentang nilai 4-7, dan yang terakhir warna merah menunjukan bahwa tingkat capaian produktifitas belum tercapai dengan rentang nilai antara 0-3.

Berdasrkan Evaluasi dengan traffic light system, kriteria yang bayak mendapatkan skor warna merah adalah kriteria 3 yaitu Rasio Rumah yang Terjual sebanyak 8, begitupun sebaliknya kriteria yang indikator warna merahnya sedikit adalah kriteria 4 yaitu Rasio Biaya Pemasaran dan Kriteria 1 yaitu Rasio Complain. Berdasarkan diskusi dengan pimpinan perusahaan salah satu faktor yang mempengarui produktivitas rumah yang terjual adalah manjemen pemasaran. Yaitu keaktifan marketing dalam melakukan promosi dan juga sistem promosi yang digunakan perusahaan.

\section{KESIMPULAN}

Berdasarkan analisa data yang telah dilakukan, Terdapat lima kriteria yang akan di gunakan untuk mengukur kinerja CV. Asthanawa Propertindo yaitu, Rasio Complain, Rasio Customer, Rasio Rumah yang Terjual, Rasio Biaya Pemasaran, dan Rasio Absensi Karyawan. Berdasarkan pembobotan kriteria mengunakan metode AHP yang diolah dengan Software Expert Chooise 11, didapatkan bobot tiap kriteria yaitu, Rasio Complain sebesar 0,43, Rasio Customer sebesar 0,26, Rasio Rumah Yang Terjual sebesar 0,06, Rasio Biaya Pemasaran Sebesar 0,16 sebesar Rasio Absensi katyawan 0.09. Penurunan Produktifitas pada periode bulan Januari sampai dengan periode bulan September 2021 terjadi pada bulan Februari sebesar -70\%, Mei sebesar -3\%, Juni $11 \%$ dan Agustus sebesar $-59 \%$, dari produktivitas sebelumnya. Dari hasil evaluasi dengan traffic light system kriteria yang mempunyai pengaruh besar terhadap penurunan produktifitas yaitu kriteria 3 yaitu Rasio rumah yang terjual. Dari diskusi dengan pimpinan perusahaan didapatkan bahwa manajemen pemasaran merupakan hal yang sangat penting khususnya industri jasa yang bergerak dalam bidang agen properti. Adapun usulan yang dapat di berikan mengevaluasi keaktifan marketing dalam melakukan promosi dan sistem promosi yang digunakan perusahaan.

\section{DAFTAR PUSTAKA}

Damayanti, S., \& Widianti, T. (2015). Pengukuran Produktivitas Peneliti Dengan Metode Integrasi Seven Steps dan Objective Matrix (Studi Kasus: Sebuah Kelompok Penelitian Pada Lembaga X). Annual Meeting on Testing and Quality 2015, 1907-7459, 280-293.

Ilhami, R. S., \& Rimantho, D. (2017). Jurnal Optimasi Sistem Industri Penilaian Kinerja Karyawan dengan Metode AHP dan Rating Scale. Jurnal Optimasi Sistem Industri, 16(2), 150-157.

Kaluku, M. R. A., \& Pakaya, N. (2017). Penerapan Perbandingan Metode AhpTopsis Dan Anp-Topsis Mengukur Kinerja Sumber Daya Manusia Di Gorontalo. ILKOM Jurnal Ilmiah, 9(2), 124-131.

Kustiadi, O., \& Hasbullah. (2019). Measuring productivity index with objective matrix (OMAX) method in the diecasting aluminum industry. International Journal of Mechanical and Production Engineering Research and Development, 9(3), 13-22.

Neely, A., \& Adams, C. (2004). Analisis Pengukuran Kinerja Rumah Sakit Dengan Menggunakan Metode Performance Prism. Encyclopedia of Social Measurement, 1(1), 41-48.

Rahman, A. A., \& Ismail, N. (2015). Designing Individual Productivity Measures In Service Sector. Universiti Teknologi Malaysia, 7, 28-38.

Ratih Ardia Sari, Rahmi Yuniarti, F. R. N. S. (2018). Evaluasi Kinerja Perusahaan Berdasarkan Perspektif. Jurnal Teknik Industri, 19(1), 49-57.

Salomon, L. L., Sukania, I. W., \& Susanto, H. 
(2017). Pengukuran Kinerja Industri Percetakan Berdasarkan Model Balanced Scorecard Dan Objective Matrix (OMAX)(Studi Kasus: PT .... (SNMI XI), April, 27-29.

Sirait, M. (2020). Analisa Produktivitas pada UKM Dompet Kulit dengan Metode Objective Matriks (OMAX). Teknoin, 26(1), 23-29. 